\title{
LINGULATE BRACHIOPODS OF TREMADOCIAN AGE FROM THE ABANDONED GABRIELA MINE (KRUŠNÁ HORA, CENTRAL BOHEMIA, CZECH REPUBLIC)
}

\author{
Michal Mergl
}

Center of Biology, Geosciences and Environmental Sciences, Faculty of Education, University of West Bohemia in Plzeň, Klatovská 51, 30619 Plzeň, Czech Republic; E -mail: Argyrotheca@seznam.cz

\begin{abstract}
Lingulate brachiopods are described from a lithic sandstone referred to the upper part of the Třenice Formation. Loose blocks were sampled from a dump of abandoned Gabriela Mine in Krušná Hora Hill near Beroun, Central Bohemia. Apart of the Acrotreta aff. grandis Klouček, 1919, genera Teneobolus, Rosobolus, Broeggeria, Rowellella and Siphonobolus are distinguished. Comments to their ontogeny, affinity, stratigraphical and spatial occurrences and taphonomy are discussed.
\end{abstract}

Key words: Lingulata, Siphonotretida, Acrotretidae, taxonomy, Tremadocian, Krušná hora, Central Bohemia

\section{INTRODUCTION}

The majority of information on taxonomy, stratigraphical and spatial distibutions of lingulate brachiopods of Early Ordovician age in the Czech Republic came from the western part of the Barrandian, especially from a small area between Rokycany and Komárov (Koliha, 1924; Havlíček, 1982a; Mergl, 2002). The most diverse lingulate assemblage with eighteen species in a single layer has been observed in reddish aleuropelites of the Olešná Member (Klabava Formation) in vicininty of Strašice, which are likely of the Floian age (Mergl, 1995, 2002). However, first reports of lingulates in the Barrandian are of much earlier data and they came from different area. The iron-ore mining in Krušná Hora Hill north of Beroun was a rich source of the earliest described lingulates from the Central Bohemia. Lipold (1863) reported from Krušná Hora Hill large zhanatellid Lingula Feistmanteli, in that time as nomen nudum. This first report was followed by Vála \& Helmhacker $(1872,1874)$ who reported the same species. First illustrations of brachiopods from Krušná Hora Hill came in Barrande (1879a). He illustrated Lingula Feistmanteli Barr., L. expulsa Barr., Discina secedens Barr. and D. socialis Barr. Next authors (Katzer, 1892; Jahn, 1904a, 1904b; Koliha, 1918, 1924) greatly repeated observations made by Barrande (1879a, 1879b) and listed few additional spe- cies, generally poorly determined lingulates. These species were nearly completely revised by Mergl (1981) and Havlíček (1982a) followed by their synopsis by Mergl (2002). Updated lists of fossils from all localitites of the Třenice Formation in Krušná Hora Hill has been presented by Kraft et al. (2013). Recently, a loose block observed at the dump of the abandoned Gabriela Mine in SW part of the Krušná hora Hill yielded the lingulate association previously unknown from the area.

\section{MATERIAL}

The studied material studied is housed in the palaeontological collections of the University of West Bohemia at Plzeň (PCZCU).

\section{GEOLOGICAL SETTING}

The Lower and early Middle Ordovician in Krušná Hora Hill form a narrow synclinal faulted structure, which is separated from the main part of the Prague Basin synform tectonicaly by several kilometres broad strip of the Proterozoic rocks (Petránek, 1974). The first historical reports about mining of iron ores of the Šárka Formation (Darriwilian) came from $15^{\text {th }}$ century, although traces after primitive mining are even older. The culmination of mining came at $18^{\text {th }}$ and in $19^{\text {th }}$ cen- 


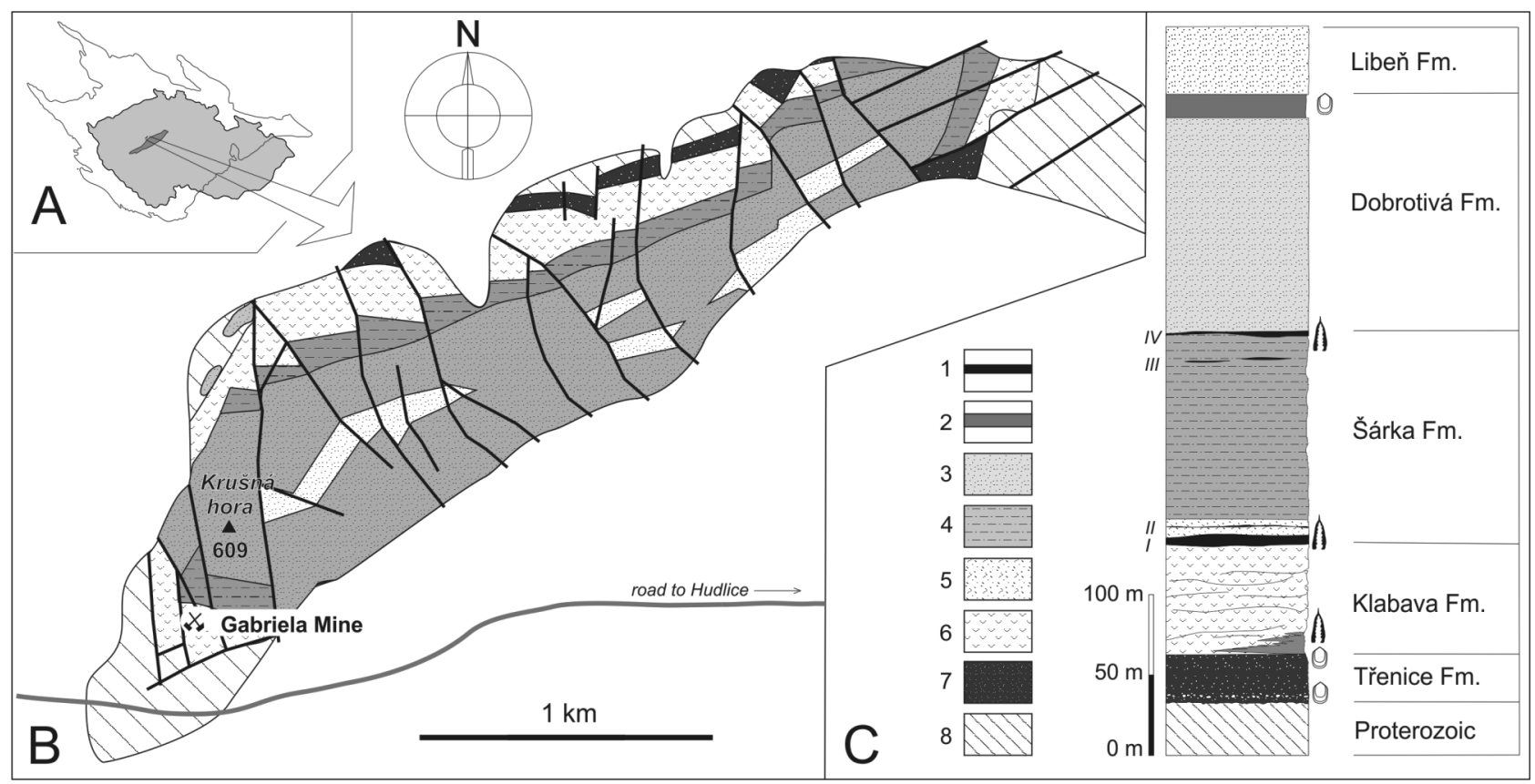

Figure 1. Schematic maps showing location of the Prague Basin in the Barrandian area in the Czech Republic with a small area of the Krušná hora (A), outcropping the Proterozoic and Ordovician rocks in the Krušná Hora area (B), and simplified stratigraphy of the Krušná hora area (after Petránek, 1974). Levels with graptolite and lingulate brachiopod fauna are indicated, based on data of Bouček (1973) and Bouček \& Svoboda (1946). Level with new fauna marked by shell with black triangle. Explanation: 1 - iron-ores (with particular mined beds marked by Latin numbers I, II, III and IV), 2 - shale, 3 - quartzose sandstone, 4 - shales alternating with sandstones, 5 - submarine basalts, 6 - basalt tuffs and aglomerates, 7 - lithic sandstone and conglomerate, 8 - Precambrian shale.

tury (Dubanský \& Weber, 1964). Mining activity ended in 1968 and only shallow pits and dumps can be observed there at present.

Lithic and quartzose sandstones, named "Dichte Grauwacke" in old mining documents from mid of $19^{\text {th }}$ Century (Lipold, 1863) are the oldest Ordovian rocks in the Krušná hora area. This pale grey-green coloured sandstone, with thickness about 50 metres was the main source of fossils in the $19^{\text {th }}$ Century. Large zhanatellid Hyperobolus feistmanteli (Barrande, 1879), associated with less abundant Expellobolus expulsus (Barrande, 1879) and rare Orbithele secedens (Barrande, 1879) are characteristic fossils of this lithic sandstone. These species of a low diversified Hyperobolus Community (Havlíček, 1982b) proliferated on shallow-water marine flat shoal that was supplied by sorted quartz sand from nearby Cambrian volcanites (Kettner, 1916; Kukal, 1963). The cherts of the subsequent Mílina Formation, in western part of the Prague Basin characterized by minute lingulates of the Thysanotos-Leptembolon Asso- ciation (Havlíček, 1982a; Mergl, 2002), have not been observed in the Krušná hora Hill area. The Třenice Formation is followed by more than $100 \mathrm{~m}$ thick Klabava Formation (Floian to Dapingian) built by tuffitic shales, tuffites, and basalt agglomerates of the Komárov Complex. The Ordovician succession follows by the Śarka Formation (Darriwilian) with basalts, their tuffs and several levels of oolithic ferrolites, the Dobrotivá Formation (Darriwilian) represented mainly by Skalka Quarzite and the Revnice Quartzite of the Liben Formation (lower Sandbian), which is the youngest Ordovician unit in the Krušná Hora area (Figure 1). Diverse graptolites, which indicate an exact age of the iron layers in the Šárka Formation were observed in Krušná hora by Bouček (1944, 1973).

The abandoned Gabriela Mine is situated at SW foot of Krušná Hora Hill. Bouček (1973) reported from this site graptolite Expansograptus extensus (Hall, 1865). Mergl (2002) reported rare occurrence of brachiopod Hyperobolus feistmateli (Bar- 
rande, 1879) from the pale grey-green lithic sandstone derived from the Třenice Formation. Recently, a loose block of greenish quarzitic sandstone yielded the distinct lingulate association, with dominance of acrotretoid and siphonotretid brachiopods.

\section{SYSTEMATIC PART}

Abbreviations used for description: DVl - dorsal valve length, DVw - dorsal valve width, $\mathrm{n}$ - number of specimens.

Order Lingulida Waagen, 1885

Superfamily Discinoidea Gray, 1840

Family Obolidae King, 1846

Genus Teneobolus Mergl, 1995

Type species: Teneobolus gracilis Mergl, 1995; Klabava Formation, Floian, Ordovician; Bohemia.

Teneobolus bukovensis (Koliha, 1924)

$\mathrm{Pl}$. I, figs $1-4$

1924 Lingulella Bukovensis n. sp.; Koliha, p. 30 and 57, pl. 2, fig. 8.

1982a Palaeoglossa bukovensis (Koliha, 1924); Havlíček, p. 37, pl. 8, figs. 1-3 (non 4).

1995 Teneobolus gracilis sp. n. (partim); Mergl, p. 104, pl. 1, fig. 2.

2002 Teneobolus bukovensis (Koliha, 1924); Mergl, 26, pl 7, figs 1-6.

Material: One dorsal valve and two fragments. Description: Shell elongate oval, approximately $10 \mathrm{~mm}$ long, with short dorsal pseudointerarea. Ventral valve is unknown in new material. Exterior bears fine flat growth bands of even size arranged in regular intervals, separated by filose concentric lines. These lines are less curved along the axial sector of the valve.

Remarks: Although poor in quality and number, the shells may be reliably referred to Teneobolus bukovensis due their size, outline and, especially, for characteristic external macroornament, which is the same with topotype specimens (Mergl, 2002, pl. 7, figs 3,4) and unknown in any other early Ordovician obolid from the Prague Basin.

Occurrence: The species is known only from the Třenice Formation. Localities: Krušná hora, Gabriela Mine (rare); Zaječov (rare), Zbiroh, Bukov, quarries (moderately common).
Family Zhanatellidae Koneva, 1986

Genus Rosobolus Havlíček, 1982a

Type species: Rosobolus robertinus Havlíček, 1982a; Třenice Formation, Tremadocian, Ordovician; Bohemia.

\section{Rosobolus sp.}

Pl. I, figs 6-10

Material: Three ventral and two dorsal valves, all incomplete.

Description: Shell is moderate thick, $10 \mathrm{~mm}$ wide, subpentagonal, with maximum width at its anterior third. Dorsal valve is subpetagonal, with rounded posterior margin, evenly convex in transverse profile and more convex posteriorly rather than anteriorly along its axial plane. Ventral valve has moderately acuminate beak having distinct pedicle groove. Interior of the dorsal valve has large elongate oval impressions of central muscles. Interior of the ventral valve has a small broadly trapezoidal visceral area. Vascula lateralia are widely divergent in their proximal parts.

Exterior with few growth bands bordered by short growth lamellae. The bands between growth lamellae are nearly smooth having weak marks of concentric growth or scars of a mantly injury. Microornament of very fine rhombic pits arranged in regular oblique intersecting rows is distinct over the entire shell exterior.

Remarks: The microornament of very small regularly arranged pits is a diagnostic feature of the genus (Popov \& Holmer, 2000; fig. 29: 1d). Other features (size, convexity, outline) are also similar to Rosobolus robertinus Havlíček, 1982a from the Třenice Formation in Holoubkov. The main difference is a poor impression of central muscles into the shell interior and less distinct visceral field in the material from the Gabriela Mine. However internal features in the type locality are often diagenetically accentuated. Rosobolus magnus Mergl, 2002 from the Třenice Formation is larger than the valves from Gabriela Mine, having less triangular outline and deeply impressesed ventral muscle scars. External microornament of $R$. magnus is unknown due to the preservation in the coarse-grained lithic sandstone. Therefore, the shells of Rosobolus from Gabriela Mine is better to determine to the generic level only. Better and much numerous shells of Rosobolus magnus, $R$. robertinus, $R$. sp. from Gabriela Mine, and 


\section{Plate I}

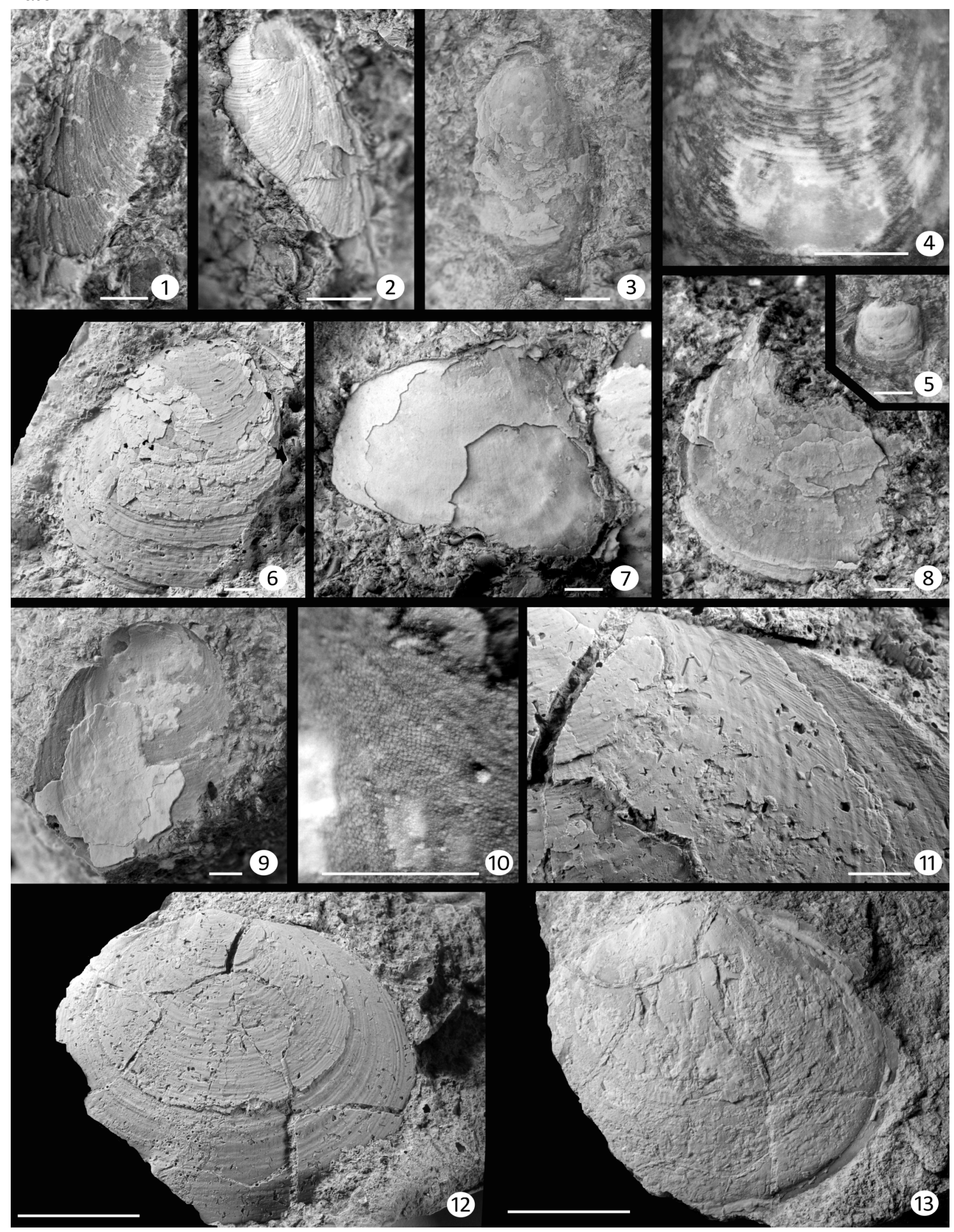


$R$. sp. from other stratigraphic levels (Mergl 2002, p. 38 , pl. 18, figs $9,11,12$ ) are necessary to elucidate affinites between these moderately-sized zhanatellids.

Occurrence: Tremadocian, Třenice Formation. Locality: Gabriela Mine (rare).

Genus Rowellella Wright, 1963

Type species: Rowellella minuta Wright, 1963; Portrane Limestone, Katian, Ordovician; Ireland.

\section{Rowellella? sp.}

Pl. I, fig. 5

Material: One valve.

Remarks: Only one minute dorsal valve $1 \mathrm{~mm}$ wide was observed. The shell is subrectangular, parallel-sided, having steeply sloping flanks and lacking the apical part. Poorly preserved external mould shows distinct concentric lamellae. Although very rare in the locality, these features are distinct and consistent with diagnostic features of the genus. The valve is similar to subrectangular specimens of Rowellella distincta Bednarczyk \& Biernat, 1978, which is a common species in the lower part of the Olešná Member (Floian) of the Klabava Formation. Occurrence: The valve represents the first known occurrence of the genus in the Třenice Formation. Other occurences of the genus in the Barrandian come from stratigraphically youger beds (Floian: Olešná Member, Klabava Formation, and Darriwilian: Šárka Formation; Mergl, 1995, 2002).

Family Elkaniidae Walcott \& Schuchert, 1908

Genus Broeggeria Walcott, 1902

Type specie: Obolella salteri Holl, 1865; Whiteleaved-Oak Shales, Furongian, Cambrian, South Wales.

\section{Broeggeria sp.}

$\mathrm{Pl}$. I, figs 11-13

Material: One dorsal valve.

Description: The dorsal valve is thin-shelled relative to size, $28 \mathrm{~mm}$ wide and $23 \mathrm{~mm}$ long (DVw/ $\mathrm{DVl}=1.22$, , subcircular in outline, rectimarginate, weakly convex in transverse and axial profiles, with maximum width at midlength. The posterior margin and sides are evenly rounded. Dorsal pseudointerarea is short, almost orthocline, with small propareas. Impressions of muscles are weakly defined except for narrow subparallel central scars confined to anteriorly extened visceral area.

The shell is ornamented by fine concentric growth lines, extended into few coarser concentric lamellae. Fine radial rays are present in posterolateral sectors of the valve (Pl. I, fig. 11). Fine microornament was not observed.

Remarks: The valve cannot be referred to any of known Tremadocian species from the Barrandian area (Mergl, 2002). The shell outline, convexity and the observed internal structures are consistent with attribution to Broeggeria Walcott, 1902 of the Elkaniidae Walcott \& Schuchert, 1908. However, the shell size is much than twice bigger than recorded maximum size in Broeggeria salteri (Holl, 1865) (see Popov \& Holmer, 1994). Broeggeria ferraria Mergl, 2002 from haematite at Holoubkov referred to the upper part of the Třenice Formation (Mergl, 2009) is a smaller species having a distinct dorsal median ridge that was not observed in the specimen from Gabriela Mine.

Occurrence: Tremadocian, Třenice Formation. Locality: Gabriela Mine (rare).

Plate I, 1-4 - Teneobolus bukovensis (Koliha, 1924). Tremadocian, Třenice Formation, dump of abandoned Gabriela Mine, Krušná hora, Barrandian. Bar = $1 \mathrm{~mm} ; 1,2)$ Incomplete ventral (?) valve, external and internal moulds with partly preserved shell, PCZCU 2234; 3) Dorsal valve, internal mould, PCZCU 2235; 4) Dorsal valve, external mould showing macroornament, uncoated, PCZCU 2236; 5 - Rowellella sp., Tremadocian, Třenice Formation, dump of abandoned Gabriela Mine, Krušná hora, Barrandian. Bar $=1 \mathrm{~mm}$. Dorsal valve, internal mould with partly preserved shell, PCZCU 2237a; 6-10 - Rosobolus sp., Tremadocian, Třenice Formation, dump of abandoned Gabriela Mine, Krušná hora, Barrandian. Bar = $1 \mathrm{~mm}(6-9)$, and $0,5 \mathrm{~mm}(10) ; 6)$ Dorsal vave, external mould with partly preserved shell, PCZCU 2238; 7) Ventral valve, internal mould with partly preserved shell, PCZCU 2237b; 8) Ventral valve, internal mould with partly preserved shell, PCZCU 2239. 9, 10 - dorsal valve, external mould with partly preserved shell, and detail of microornament PCZCU 2240; 11-13 - Broeggeria sp., Tremadocian, Třenice Formation, dump of abandoned Gabriela Mine, Krušná hora, Barrandian. Bar = $1 \mathrm{~mm}($ fig. 11) and $10 \mathrm{~mm}$ (Figs 12,13). Dorsal valve, internal mould (12), external mould (13) and latex casts of macroornament (11), PCZCU 2196. 
Superfamily Acrotheloidea Walcott \& Schuchert, 1908

Family Acrothelidae Walcott \& Schuchert, 1908

Subfamily Acrothelinae Walcott \& Schuchert, 1908

Genus Orbithele Sdzuy, 1955

Type species: Discina contraria Barrande, 1868; Leimitz Shale, Tremadocian, Ordovician; Bavaria.

Orbithele discontinua (Mergl, 1981)

Pl. II, figs 10, 11, 13, 14

1927 Orbiculoidea sodalis var. undulosa (Barr.); Růžička, p. 9.

1981 Orbithele discontinua sp. n.; Mergl, p. 288, pl. 1, figs $1-8$.

2002 Orbithele discontinua Mergl, 1981; Mergl, p. 48, pl. 25, figs $1-11,13,14$.

Material: One dorsal and five ventral valves preserved as minute fragments.

Description: See Mergl (2002).

Remarks: New material shows the same complex ornament of irregular fila with pustules described by Mergl (2002). New shells fall within the size range of the species noted by Mergl (2002). Larger and coarsely rugellate Orbithele secedens (Barrande, 1879) is known also from the Krušná hora mines (Barrande, 1879; Mergl, 2002) but this species is associated with Hyperobolus feistmanteli and likely stratigraphically preceded $O$. discontinua Mergl, 1981.

Occurrence: The species is known only in the Třenice Formation. Localities: Cheznovice, Žlebec (rare); Holoubkov, V Ouzkém (common); Krušná Hora, Gabriela Mine (common); Skomelno, $\mathrm{Na}$ Solích (common).
Order Acrotretida Kuhn, 1949

Superfamily Acrotretoidea Schuchert, 1893

Family Acrotretidae Schuchert, 1893

Genus Acrotreta Kutorga, 1848

Type species: Acrotreta subconica Kutorga, 1848; Floian (regional Billingen Stage); Ordovician, environs of St. Petersburg, Russia.

Acrotreta aff. grandis Klouček, 1919

Pl. II, figs 1-9, 12

Material: Fifteen dorsal and three ventral valves. Description: Shell is thick-walled, $1.6 \mathrm{~mm}$ wide in the largest individual. Dorsal valve is circular in outline $(\mathrm{DVw} / \mathrm{DVl}=1.019, \min .=0.928, \max .=$ $1.126, \mathrm{n}=11$ ), moderately convex in transverse and axial profiles, without trace of sulcus. Dorsal pseudointerarea is anacline, broadly triangular, large (length of pseudointerarea $=15 \%$ of $\mathrm{DVl}$ ), with broadly triangular median groove and narrow small propareas. Median buttres is small. Dorsal median septum is low and broad, evenly high along its length, extending anteriorly to almost $75 \%$ of DVl. Cardinal muscle scars are large, occuppying almost the entire posterolateral corners of the shell floor, leaving only a narrow marginal strip along posterolateral valve floor. Anterocentral muscle scars are small and weakly impressed along the median ridge. Vascula lateralia are widely divergent, with broad distinctly impressed proximal parts. The distal portitions are obscure. The deeply concave floor of the dorsal valve is surrounded by a broad brim along sides and frontal parts of the valve. Ventral valve is acutely conical, with catacline pseudointerarea. Short pedicle tube piercing the apex is supported by short median ridge.

Plate II, 1-9, 12 - Acrotreta aff. grandis Klouček, 1919. Tremadocian, Třenice Formation, dump of abandoned Gabriela Mine, Krušná hora, Barrandian. Bar $=1 \mathrm{~mm}$; 1) Dorsal valve, internal mould, PCZCU 2241; 2) Dorsal valve, internal mould, PCZCU 2242; 3) Dorsal valve, internal mould, PCZCU 2243; 4, 8) Dorsal valve, internal mould with partly preserved shell, and the same in oblique view, PCZCU 2244; 5) Dorsal valve, internal mould with partly preserved shell, PCZCU 2245; 6, 9) Dorsal valve with original shell showing exterior, and the same in oblique view showing shell convexity, PCZCU 2246; 7,12 ) Ventral valve with broken apex and original shell, and its external mould showing macroornament, PCZCU 2247; 10, 11, 13, 14 - Orbithele discontinua Mergl, 1981. Tremadocian, Třenice Formation, dump of abandoned Gabriela Mine, Krušná hora, Barrandian. Bar $=1 \mathrm{~mm} ; 10$ ) Ventral valve, latex cast of exterior, PCZCU 2248; 11) Ventral valve, external mould, PCZCU 2249; 13, 14) Ventral valve, internal mould and detail of macroornament on early postlarval shell, PCZCU 2250; 15-18 - Siphonobolus simulans (Růžička, 1927). Tremadocian, Třenice Formation, dump of abandoned Gabriela Mine, Krušná hora, Barrandian. Bar $=1 \mathrm{~mm}$; 15) Ventral valve, external mould, uncoated, showing concentric lines of uniformly sized spines, PCZCU 2251; 16) Dorsal valve with partly preserved shell showing holes after broken spines, external mould, PCZCU 2249; 17, 18) Ventral valve with partly preserved shell showing inner opening of spines (17), and detail of exterior with bases of spines (18), PCZCU 2237c. 


\section{Plate II}

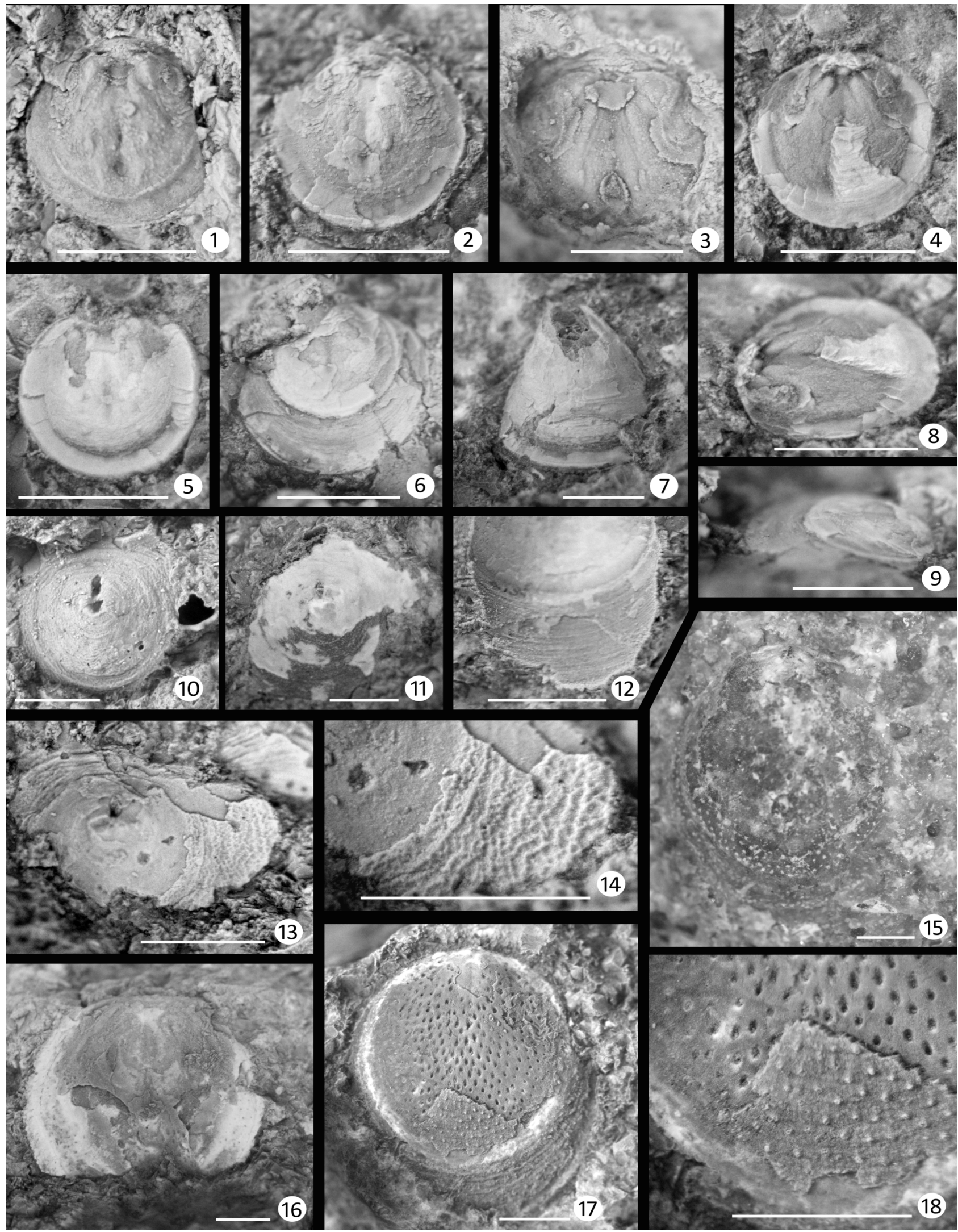


Ornamentation consists of fine concentric fila of uniform size with ten fila per $0.1 \mathrm{~mm}$. Prominent concentric lamellae may form moderate stepped side profile.

Remarks: All available shells, almost exclusively the dorsal valves, are of nearly the same size and shape (Fig. 2), having unusually thick shell relative to their size. The dorsal valves are similar to those of Acrotreta grandis Klouček, 1919 and related to the chronologically subsequent large acrotretids (A. foetida Mergl, 2002, A. scabra Mergl, 2002) from the Prague Basin. However, the mentioned three species are about three times larger and the convexity of their dorsal valves is less prominent, internally leaving only a weakly concave floor, different from a deeply concave dorsal valve of $A$. aff. grandis. This size difference between shells of $A$. aff. grandis and $A$. grandis cannot be related only to age of the individuals because the dorsal valves of $A$. aff. grandis are distinctly thickwalled unlike to relatively thin-walled $A$. grandis of comparable size. There are little doubts, that $A$. grandis and $A$. aff. grandis are closely related species. Unfortunately, the modes of preservation of $A$. grandis and $A$. aff. grandis restrict the data about shell microornament, nature of the larval shells and other important morphological features. Acrotreta dissimilis (Biernat, 1973) from Tremadocian chalcedonites of Poland has a shorter and narrower dorsal median septum. The microornament with small pustules illustrated by Holmer \& Biernat (2002; fig. 7 O) was not observed in A. aff. grandi but this may be due to a poor preservation of the latter taxon in the lithic sandstone.

Specimens referred to Dactylotreta sp. from the Třenice Formation near Cheznovice (Mergl, 2012) cannot be referred to A. aff. grandis. Available dorsal valves from Cheznovice, Žlebec (Kraft et al. 2013) display thin dorsal median septum but their preservation in lithic sandstone is very poor and not suitable for more accurrate comparison.

Occurrence: Tremadocian, Třenice Formation. Locality: Gabriela Mine (abundant).
Order Siphonotretidae Kutorga, 1848

Superfamily Siphonotretoidea Kutorga, 1848

Family Siphonotretidae Kutorga, 1848

Subfamily Siphonotretinae Kutorga, 1848

Genus Siphonobolus Havlíček, 1982a

Type species: Siphonotreta simulans Růžička, 1927; Třenice Formation, Tremadocian, Ordovician; Bohemia.

Siphonobolus simulans (Růžička 1927)

Pl. II. figs 15-18, Pl. III, figs 1-13.

1927 Siphonotreta simulans n. sp.; Růžička, p. 7, pl. 1, figs 10-12.

1927 Obolus complexus Barr.; Růžička, p. 4.

1982a Siphonobolus simulans (Růžička, 1927); Havlíček, p. 62, pl. 11, figs 1-7, text-fig. 12.

2002 Siphonobolus simulans (Růžička, 1927); Mergl, p. 62, pl. 39, figs 11-15.

2012 Siphonobolus simulans (Růžička, 1927); Mergl, p. 141, pl. 2 D, E, CH.

Material: Twenty-five ventral and five dorsal valves. Description: See Havlíček (1982a) and Mergl (2002). Remarks: Siphonobolus simulans is rare species in the type locality at Holoubkov (V Ouzkém). In addition, the preservation in quartzitic haematite emphasized some internal features and suppressed others. New material although not perfectly preserved makes possible some corrections.

The young specimens observed in the new material show a large pedicle opening with a very short pedicle tube in the thin shell and no traces of the median septum (Pl. III, fig. 4). The shell is thus similar to Acanthambonia Cooper, 1956. With subsequent growth, the tube becomes long and thin and short median septum becomes to develop, supporting and stabilizing the ventral side of the pedicle tube on the valve floor (Pl. III, figs 3,5 ). The outline of the shell also changed during the ontogeny. The almost circular shell in small specimens (Pl. III, fig. 4) becames a distinctly elongate oval in adults (Pl. III, fig. 7).

Plate III, Siphonobolus simulans (Růžička, 1927). Tremadocian, Třenice Formation, dump of abandoned Gabriela Mine, Krušná hora, Barrandian. Bar = $1 \mathrm{~mm}$; 1) Small ventral valve, internal mould, PCZCU 2253; 2) Small ventral valve, internal mould, PCZCU 2254; 3, 11) Small ventral valve, internal mould, and the same in oblique view, PCZCU 2255; 4) Small ventral valve, internal mould, PCZCU 2256a; 5) Ventral valve, internal mould, PCZCU 2257; 6) Ventral valve, internal mould, PCZCU 2258; 7, 13) Ventral valve, internal mould, and the same in oblique view PCZCU 2256b; 8) Ventral valve, internal mould, PCZCU 2251; 9, 12) Dorsal valve, internal mould, and the same in oblique view, PCZCU 2259; 10) Dorsal valve, internal mould, PCZCU 2260. 


\section{Plate III}

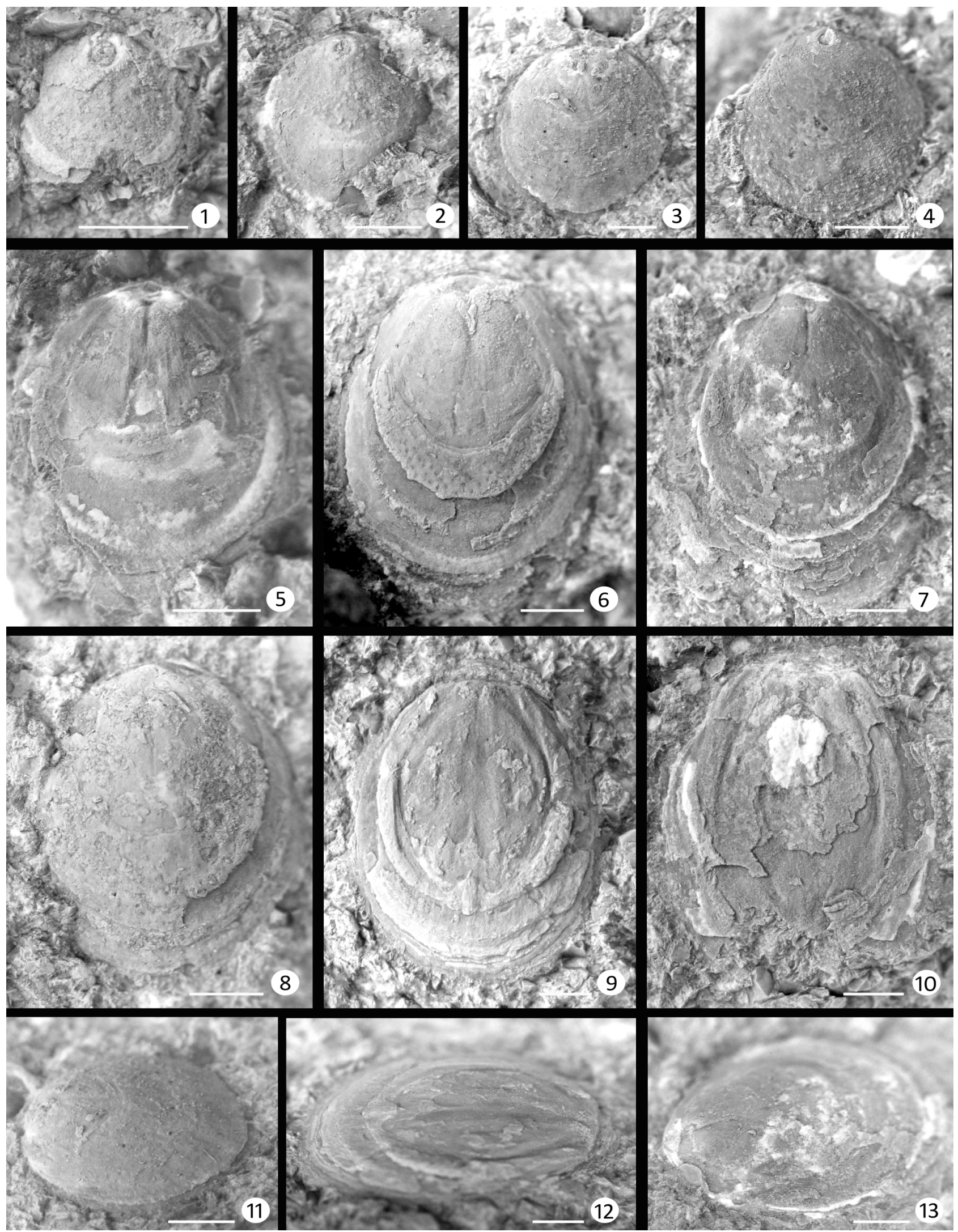


Ontogenic development of the ventral median ridge iterated the evolution of the genus.

The Furongian Siphonobolus priscus Popov, Holmer, Bassett et Ghobadi Pour, 2009 from the Shirgesht Formation of the Derenjal Mountains of Iran lacks the median septum in the ventral interior. Noteworthy, the stratigraphically subsequent Siphonobolus kalshanensis Popov, Holmer, Bassett et Ghobadi Pour, 2009 from the same formation and area has clearly developed median ridge (Popov et al. 2009, fig. 5J). However, presence of the ventral median ridge is not likely the universal novellity of the genus developed near the base of the Tremadocian. The species Siphonobolus uralensis (Lermontova, 1933), which is the late Tremadocian to Floian in age (Kidryas Formation, Ural Mountains) also lacks the ventral median ridge (Popov \& Holmer, 1994). Unlike to Siphobolus priscus and $S$. uralensis, the new material of the mid- to late Tremadocian $S$. simulans show a distinct ventral median ridge. This feature indicates a closer relationship of $S$. simulans to the earlier but also Gondwanan S. kalhamensis than approximately coeval $S$. uralensis from the margin of Baltica.

Exterior of Siphonobolus is characterised by fine spines of uniform size arranged in concentric bands (Pl. II, fig. 15). The spines are internally opened by minute holes resting on minute knoblike pads on valve floor (Pl. II, fig. 17). Externally, the spines are very low angled toward shell surface. Uniform size and higher density of spines distinguish the genus from Eosiphonotreta Havlíček, 1982a, which has spines of uneven size (see also Mergl, 2002, pl. 40, fig. 10).

Presence of the ventral median septum distinguishes Siphonobolus from Eosiphonotreta, Siphonotretella Popov et Holmer 1994 and Celdobolus Havlíček, 1982a. Dorsal pseudointerarea is remarkably high in Siphonobolus (Pl. III, figs 9, 12) featuring the pseudointerarea of Celdobolus.

Occurrence: The species is known only in the Třenice Formation (Tremadocian). Localities: Cheznovice, Žlebec (rare); Holoubkov, V Ouzkém (common); Krušná Hora, Gabriela Mine (common).

\section{DISCUSSION}

\section{Age of fauna}

The taxonomic composition of lingulate brachiopod fauna observed in the dump of the Gabriela Mine is remarkable by a dominance of siphonotretid Siphonobolus simulans. This species is known only from the Třenice Formation. Small obolid Teneobolus bukovensis is known from the Třenice and Mílina formations, but in the latter unit is very rare. Rosobolus is common species in the Třenice Formation, but its stratigraphical range is much longer, with the latest known species from the upper part of the Klabava Formation (Dapingian). In summary, an absence of large species Hyperobolus feistmanteli and Expellobolus expulsus, the index taxa for the Třenice Formation coming from the Krušná Hora Hill mines, which are common in grey-green lithic sandstones in dump of Gabriela Mine, indicate that the sandstone with Siphonobolus simulans is likely younger than that bearing Hyperobolus feistmanteli. Correspondingly, a suggested stratigraphical level with the new fauna is the upper part of the Třenice Formation. This suggestion is in agreement with occurrence of Siphonobolus simulans at Holoubkov locality and in the Cheznovice area. In these two localities this species occurs in the upper part of the Třenice Fomation together with eoorthids but before an onset of the Thysanotos-Leptembolon Association, which subsequently persisted in the SW part of the basin into the Floian or even the Dapingian (Olešná Member). Acrotreta aff. grandis is not known from other localities. Acrotretoids of the Mílina Formation and the Olešná Member are sufficiently known (Mergl, 1995, 2002). Indeed, the absence of $A$. aff. grandis in cherts of the Mílina Formation indirectly supports an older age of the lithic sandstone with lingulates from Gabriela Mine.

\section{Taphonomy and environment}

New association is preserved in the lithic sandstone. Monocrystalline quartz grains, angular to subangular and subequal size (Figure 2) are associated with microcrystalline aphanitic volcanics and small fragments of phosphatic shells. Strong fragmentation, uneven orientation of shells and absence of characteristic sedimentary structures could be explained by transport and deposition the sandstone bed from a debris flow. 


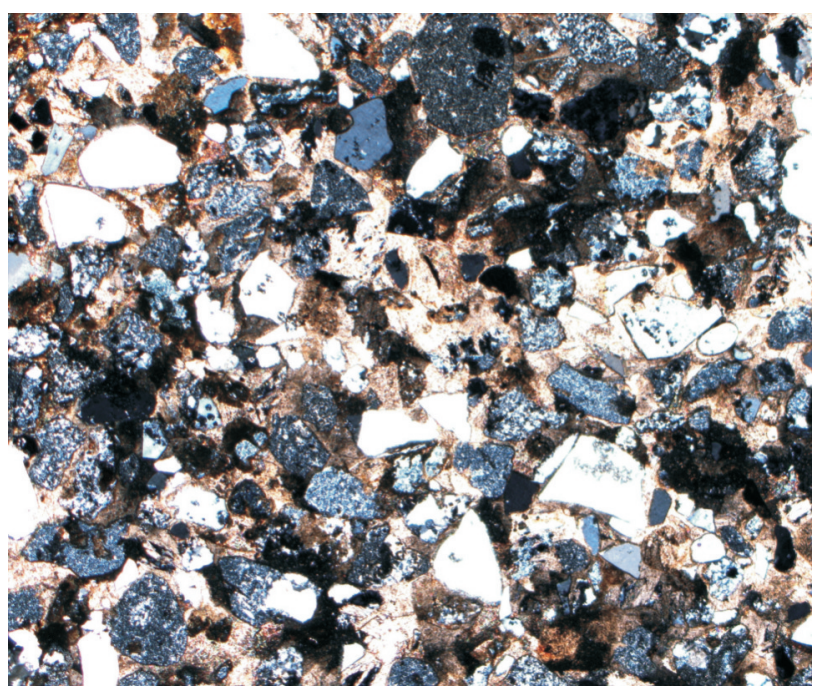

Figure 2. Photomicrograph of lithic sandstone from Gabriela mine with subangular monocrystalline quartz and lithic fragments

The presence of epifaunal microbrachiopods (Acrotreta, Rowellella), epifaunal fixo-sessile macrobrachiopods (Siphonobolus, Orbithele) and likely semiinfaunal to infaunal taxa (Rosobolus, Teneobolus) indicate tiering in more levels on stable substrate, both firm substrate (rock, algal mats, kelp surface?) and motile sand. In summary, the favourable and relatively stable environment inhabited by moderately diverse micro- and macrobrachiopods was affected by a flow of coarse volcanogenic debris. Therefore, the newly observed brachiopod occurrence is assumed to be allochtonous unlike to parautochtonous occurrences of Hyperobolus in the lithic sandstone in another stratigraphic levels. Unlike to newly described fauna, the shells of Hyperobolus feistmanteli are generally oriented parallel to bedding planes and are less intensively fragmented indicating only moderate transport and wave and current generated orientation in sand dunes (Hroch et al. 2012).

\section{CONCLUSION}

New fauna observed in dump of the abandoned Gabriela Mine referred to the Třenice Formation differs from local famous lingulate fauna with $H y$ perobolus feistmanteli, which is the most common fauna in the grey-green lithic sandstone in the area. The new fauna is dominated by acrotretid Acrotreta aff. grandis and siphonotretid Siphonobo- lus simulans. Presence of Rosobolus, Teneobolus and Orbithele makes this association similar to roughly coeval fauna from SW part of the Prague Basin. Mode of preservation indicates that the deposition of the lithic sandstone with the new fauna was likely from a debris flow.

\section{ACKNOWLEDGEMENTS}

This is contribution to IGCP Project 653: The onset of the Great Ordovician Biodiversity Event. I thank Leonid Popov (Cardiff) and Lars E. Holmer (Uppsala) for critical comments and some suggestions on the manuscript.

\section{REFERENCES}

Barrande, J. 1879a. Systême silurien du centre de la Bohême. $1^{\text {ère }}$ Partie: Recherches Paléontologiques. Vol. 5. Classe des Mollusques. Ordre des Brachiopodes. Planches 72-153. Pls. 72153. Prague and Paris.

Barrande, J. 1879b. Systême silurien du centre de

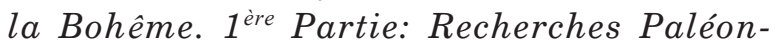
tologiques. Vol. 5. Classe des Mollusques. Ordre des Brachiopodes. Trois chapitres de texte et Planches. 226 pp., pls. 1-71. Prague and Paris.

Bednarczyk W., Biernat, G. 1978. Inarticulate brachiopods from the Lower Ordovician of the Holy Cross Mountains, Poland. Acta Palaeontologica Polonica 23(3), 293-316.

Biernat, G. 1973. Ordovician inarticulate brachiopods from Poland and Estonia. Palaeontologia Polonica 28, 120.

Bouček, B. 1944. O nových nálezech graptolitů v českém ordoviku. Věda př́rodní 22, 226-233.

Bouček, B. 1973. Lower Ordovician graptolites of Bohemia. 155 pp. Academia. Praha.

Bouček, B., Svoboda, J. 1946. Příspěvek k výskytu křemité facie ve vrstvách dobrotivských $\mathrm{D}_{\gamma 2}$ českého ordoviku. Věstník Královské české společnosti nauk, tř́da matematicko-př́rodovědecká 1945, 12, 1-8.

Dubanský, A., Weber, B. 1964. Železnorudné ložisko Krušná hora u Berouna. Sborník Vysoké školy chemicko-technologické v Praze, Mineralogie 6, 329-369.

Gray, J.E. 1840. Synopsis of the contents of the British Museum, $42^{\text {th }}$ edition. 370 pp. British Museum, London. 
Havlíček, V. 1982a. Lingulacea, Paterinacea, and Siphonotretacea (Brachiopoda) in the Lower Ordovician sequence of Bohemia. Sbornik geologických věd, Paleontologie 25, 9-82.

Havlíček, V. 1982b. Ordovician in Bohemia: Development of the Prague Basin and its benthic communities. Sborník geologických věd, Geologie 37, 103-136.

Havlíček, V., Šnajdr, M. 1956. Paleogeografie tremadockého moře v Barrandienu. Sborník Ústředního ústavu geologického 22, 237-255.

Holl, H.B. 1865. On the geological structure of the Malvern Hills and adjacent areas. Geological Society of London, Quarterly Journal 21, 72102.

Holmer, L.E., Biernat, G. 2002. Lingulate brachiopods from Lower Ordovician (Tremadoc) chalcedonites, Holy Cross Mountains, Poland. Acta Palaeontologica Polonica 47 (1), 141-156.

Holmer, L.E., Popov L.E. 2000. Lingulata. 30-146. In Williams, A., Brunton, C.H.C., Carlson, S.J. et al. Treatise on Invertebrate Paleontology, part H, Brachiopoda, Revised, Volume 2. Geological Society of America Inc. and The University of Kansas, Boulder, Lawrence.

Hroch, T., Rajchl, M., Kraft, P., Raprich, V. 2012. Sedimentary records of subaerial volcanic activity in the basal Ordovician shoal-marine deposits: the Třenice Formation of the Prague Basin, Bohemian Massif, Czech Republic. Bulletin of Geosciences 87(2), 359-372.

Jahn, J.J. 1904a. O krušnohorských vrstvách (d1 $\alpha)$. Rozpravy České Akademie pro vědy, slovesnost a umění, Tř́da II 13, 30, 1-16.

Jahn, J.J. 1904b. Über die Brachiopodenfauna der Bande D1. Verhandlungen der kaiserlichköniglichen geologischen Reichsanstalt 1904, 12, 270-280.

Katzer, F. 1892. Geologie von Böhmen. Der geognostische Aufbau und die geologische Entwickelung des Landes. Mit besonderer Berücksichtigung der Erzvorkommen und der verwendbaren Minerale und Gesteine. 1606 pp. I. Taussig, Prag.

Kettner, R. 1916. Příspěvek k petrografii vrstev krušnohorských $(\mathrm{d} 1 \alpha)$. Část 1 a 2. Rozpravy České akademie pro vědy a umění, Tř́da II 24, 34, 1-64.

King, W. 1846. Remarks on certain genera belonging to the class Palliobranchiata. Annals and
Magazine of Natural History (series 1) 18, 2642.

Klouček, C. 1919. Novinky z krušnohorských vrstev - d1?. Část IV. Rozpravy České Akademie pro vědy, slovesnost a umění, Tř́da II 27, 38, $1-6$.

Koliha, J. 1918. Brachiopoda z krušnohorských vrstev - $\mathrm{d}_{1 \alpha}$. Časopis Musea Království českého 92, 128-139.

Koliha, J. 1924. Atremata z krušnohorských vrstev $\left(\mathrm{d}_{\alpha}\right)$. Palaeontographica Bohemiae 10, $1-61$.

Koneva, S.P. 1986. Novoe semeistvo kembriiskikh bezzamkovykh brakhiopod [A new family of the Cambrian inarticulate brachiopods]. Paleontologicheskii Zhurnal 1, 49-55.

Kraft, J., Mergl, M., Hroch, T., Kraft, P. 2013. Index of fossiliferous localities of the Třenice Formation (Lower Ordovician of the Prague Basin, Czech Republic). Folia Musei Rerum Naturalium Bohemiae Occidentalis, Geologica et Palaeobiologica 47(1-2), 33-64.

Kuhn, O. 1949. Lehrbuch der Paläozoologie. 326 pp. Schweizerbart, Stuttgart.

Kukal, Z. 1961. Složení a vznik ordovických sedimentů vrstev třenických a mílinských. Sborník Ústředního ústavu geologického 28, 265-307.

Kutorga, S.S. 1848. Ueber die Brachiopoden-familie der Siphonotretaceae. Russisch-Kaiserliche Mineralogische Gesellschaft zu St. Petersbourg, Verhandlungen 1847, 250-286.

Lermontova, E.V., Razumovskij, N. K. 1933. O drevnejshikh otlozheniyakh Urala (nizhnij silur i kembrij v okresnosyakh derevni Kidryasovo na yuzhnom Urale. Zapiski Rossijskogo Mineralogicheskogo Osbhchestva 62(1): 185-217.

Lipold, M.V. 1863. Die Eisensteilager der silurischen Grauwackenformation in Böhmen. Jahrbuch der k. k. geologischen Reichsanstalt 13, 339-448.

Menke, C.T. 1828. Synopsis methodica molluscorum generum omnium et specierum earum quae in Museo Menkeano adservantur. 91 pp. G. Uslar, Pyrmonti.

Mergl, M. 1981. The genus Orbithele (Brachiopoda, Inarticulata) from the Lower Ordovician of Bohemia and Morocco. Věstník Ústředního ústavu geologického 56(5), 287-292.

Mergl, M. 1995. New lingulate brachiopods from the Milina Formation and the base of the Kla- 
bava Formation (late Tremadoc - early Arenig), Central Bohemia. Věstník Ústředního ústavu geologického 70(2), 101-114.

Mergl, M. 2002. Linguliformean and craniiformean brachiopods of the Ordovician (Třenice to Dobrotivá Formations) of the Barrandian Bohemia. Acta Musei Pragae, Series B, Historia Naturalis 58(1-2), 1-82.

Mergl, M. 2009. Sukcese fosilních asociací třenického souvrství (tremadoc, ordovik) u Holoubkova (pražská pánev). Zprávy o geologických výzkumech $v$ roce 2008, 101-103.

Mergl, M. 2012. Fosilní fauna třenického souvrství (ordovik, tremadok) u Cheznovic (jihozápadní část Barrandienu). Zprávy o geologických výzkumech $v$ roce $2011,45,139-143$.

Petránek, J. 1974. Sedimentární železné rudy v ordoviku Krušní hory. Sborník Ústředního ústavu geologického, Ložisková geologie, mineralogie 16, 165-195.

Popov, L. E., Holmer, L. E. 1994. Cambrian-Ordovician lingulate brachiopods from Scandinavia, Kazakhstan, and South Ural Mountains. Fossils and Strata 35, 1-156.

Popov, L.E., Bassett, M.G., Holmer, L.E., Ghobadi Pour, M. 2009. Early ontogeny and soft tissue preservation in siphonotretide brachiopods: New data from the Cambrian-Ordovician of Iran. Gondwana Research 16, 151-161.

Růžička, R. 1927. Fauna vrstev Eulomových rudního ložiska u Holoubkova (v Ouzkém).
Část II. Rozpravy České akademie věd a umění $36,60,1-21$.

Schuchert, C. 1893. Classification of the Brachiopoda. American Geologist 11, 141-167.

Sdzuy, K. 1955. Die Fauna der Leimitz-Schiefer (Tremadoc). Senckenbergische naturforschende Gesellschaft 492, 1-73.

Vála, J., Helmhacker, R. 1872. Rudy železné v krajině mezi Prahou a Berounem. Archiv pro př́rodovědecký výzkum Čech 2, 1, 87-336.

Vála, J., Helmhacker, R. 1874. Das Eisensteinvorkommen in der Gegend zwischen Prag und Beraun. Archiv der naturwissenschaftliche Landesdurchforschung von Böhmen 2, 2, Theil 1. 102-407.

Waagen, W. 1885. Salt Range fossils, I. ProductusLimestone fossils, Brachiopoda. Memoirs of the Geological Survey of India, Palaeontologica Indica (series 13) 4(5), 729-770.

Walcott, C.D. 1902 Cambrian Brachiopoda: Acrotreta; Linnarssonella; Obolus; with descriptions of new species. United States National Museum, Proceedings 25, 577-612.

Walcott, C.D. 1908. Cambrian Geology and Paleontology. No. 3 - Cambrian Brachiopoda, descriptions of new genera and species. Smithsonian Miscellaneous Collections 53, 53-137.

Wright, A.D. 1963. The fauna of the Portrane Limestone. 1. The inarticulate brachiopods. British Museum (Natural History), Bulletin (Geology) 8(5), 221-254. 